\title{
The Case against a Plain Feel Exception to the Warrant Requirement
}

Recently several courts have applied a new exception to the requirement that a search be authorized by a warrant in order to be reasonable under the fourth amendment. Referred to here as the "plain feel" exception, and modeled after the widely recognized "plain view" doctrine, this newly created exception to the warrant requirement has thwarted criminal defendants' attempts to suppress evidence on the ground that it is the product of an illegal search and seizure. ${ }^{1}$ The exception essentially provides that where officers feel an object in the course of legitimate police conduct, and this provides probable cause for a further search or seizure, the further intrusion need not be authorized by a warrant.

This comment examines the relationship between the plain view exception and the nascent plain feel exception. ${ }^{2}$ Analyzing the arguments for and against this extension of the plain view doctrine, this comment concludes that the plain feel exception conflicts with well-established fourth amendment principles.

Part I traces the development of the plain feel exception. Part II critically examines the rationales for plain view and finds that they fail to provide a satisfactory basis for a plain feel exception. Finally, part III points out several contexts in which such an exception would flout current Supreme Court doctrine by expanding the carefully limited extant exceptions to the fourth amendment's warrant and probable cause requirements.

1 United States v. Russell, 670 F.2d 323 (D.C. Cir. 1982); United States v. Ocampo, 650 F.2d 421 (2d Cir. 1981); People v. Waterbury, 142 Cal.App.3d 1010, 191 Cal.Rptr. 835 (1983) (opinion deleted from official reporter by order of the California Supreme Court, Aug. 18, 1983); State v. Ortiz, 4 Haw.App. 143, 662 P.2d 517 (1983), vacated on this issue but aff'd on other grounds, 67 Haw. 181, 683 P.2d 822 (1984).

2 The ambiguous nature of this relationship seems to have been recognized by Professor LaFave, a leading fourth amendment scholar. The first edition of LaFave's treatise suggested that plain view encompasses "plain touch" and "plain smell"; a later edition maintains that unenhanced noises and scents should be treated according to the plain view analysis, but does not attempt to clarify the current ambiguity as to plain feel. Compare Wayne R. LaFave, 2 Search and Seizure: A Treatise on the Fourth Amendment $\S 7.2(\mathrm{e})$ (Supp. 1982) with Wayne R. LaFave, 2 Search and Seizure: A Treatise on the Fourth Amendment $\S \S 7.2(\mathrm{~d}), 6.7,5.2(\mathrm{j})$, and $2.2(\mathrm{a})$ (1987). 


\section{Development of the Plain Feel Exception}

\section{A. The Plain View Backdrop}

The fourth amendment provides that " $[t]$ he right of the people to be secure in their persons, houses, papers, and effects, against unreasonable searches and seizures, shall not be violated, and no Warrants shall issue, but upon probable cause." Although the text of the amendment does not specify the circumstances in which a warrant is required, or alternatively when the search and seizure limitation shall be one of simple reasonableness, the Supreme Court has interpreted the provision as expressing a presumption that a search warrant is required. ${ }^{3}$ When police believe it is necessary to search or seize one's person, home, or effects, they generally must have probable cause to believe their search or seizure will produce evidence of illegal conduct.. And usually police must obtain a warrant that particularly describes the place to be searched and the items to be seized, ${ }^{5}$ unless the context of the search or seizure falls within a recognized exception to the warrant requirement. The judicially crafted exclusionary rule enforces these requirements by excluding evidence seized in contravention of the fourth amendment and by excluding evidence seized pursuant to a warrant if the warrant was issued on the basis of information obtained in violation of the fourth amendment. ${ }^{6}$

At the threshold of this analysis, courts must ascertain whether a given police practice affects a cognizable fourth amendment interest-whether, in other words, the individual claiming protection has a legitimate expectation of privacy that would be impinged by a particular search or seizure. ${ }^{7}$ If no such expectation

${ }^{3}$ See, e.g., United States v. Ventresca, 380 U.S. 102, 106 (1965); Beck v. Ohio, 379 U.S. 89, 96 (1964).

1 There are several areas of government and police conduct in which probable cause, as traditionally understood, is not needed to justify fourth amendment searches, including administrative searches, see Camara v. Municipal Court, 387 U.S. 523 (1967), and protective patdowns during investigative stops, see Terry v. Ohio, 392 U.S. 1 (1968).

3 The Court has explained that police are in the "competitive enterprise of ferreting out crime" and thus may be unable to determine fairly whether the level of suspicion justifies an intrusion. Determinations by a "neutral and detached magistrate," by comparison, are less subject to institutional pressure and tend to produce a more complete factual record for later judicial review. See Johnson v. United States, 333 U.S. 10, 14 (1948).

- See Mapp v. Ohio, 367 U.S. 643 (1961).

z Katz v. United States, 389 U.S. 347 (1967). Such expectations must be both subjectively held and objectively reasonable. See id. at 360, 361 (Harlan, concurring). Justice Harlan set the standard that has prevailed since. See Oliver v. United States, 466 U.S. 170, 177 (1984). For a critical view of this standard, see Anthony G. Amsterdam, Perspectives on the Fourth Amendment, 58 Minn. L. Rev. 349, 384 (1974) (noting that by announcing intru- 
exists, no fourth amendment "search" has taken place..$^{8}$ If a fourth. amendment interest is at stake, the court "must balance the nature and quality of the intrusion on the individual's fourth amendment interests against the importance of the governmental interests alleged to justify the intrusion." This balancing guides the court in deciding whether a particular category of searches or seizures de-. mands a warrant, ${ }^{10}$ whether probable cause or some lesser degree of suspicion is required if no warrant is issued, ${ }^{11}$ and what the appropriate scope of the government's intrusion should be. ${ }^{12}$

This categorical balancing approach has generated a number of exceptions to the fourth amendment's presumptive requirement of a warrant for searches and seizures, the most pertinent here being the "plain view" exception. This exception provides that if police have justifiably entered a constitutionally protected areajustification provided either by a warrant or by an exception to the warrant requirement-they may search or seize anything in plain view if they have probable cause to associate it with criminality, even if that search or seizure is beyond the scope of the initial intrusion. The viewing or inspection that provides probable cause to support the search or seizure is not technically a fourth amendment "search"; once probable cause is established, the further intrusion of searching or seizing does not require a warrant. ${ }^{13}$

The Supreme Court refined the plain view exception in Coolidge $v$. New Hampshire. ${ }^{14}$ Coolidge involved the warrantless

sive activities, the government can always eliminate subjective expectations of privacy).

s See California v. Ciraolo, 106 S.Ct. 1809 (1986); Oliver, 466 U.S. at 177 ("open fields" doctrine).

- United States v. Place, 462 U.S. 696, 703 (1983). See also Delaware v. Prouse, 440 U.S. 648,654 (1979) ("the permissibility of a particular law enforcement practice is judged by balancing its intrusion on ... Fourth Amendment interests against its promotion of legitimate government interests"); Terry, 392 U.S. 1 (upholding police officers' protective patdowns of criminal suspects without probable cause); Camara, 387 U.S. 523 (announcing a special and relaxed standard of probable cause for "administrative" warrants).

${ }^{10}$ Camara, 387 U.S. at 528.

1 Terry, 392 U.S. at 20; Prouse, 440 U.S. at 663.

12 United States v. Sharpe, 470 U.S. 675 (1985); Terry, 392 U.S. at 20. For a more expansive discussion of the intricacies of fourth amendment law, see generally 2 LaFave Treatise (1987 ed.) (cited in note 2).

1s See Arizona v. Hicks, 107 S.Ct. 1149, 1152-53 (1987). Earlier cases alluding to such an exception include Harris v. United States, 390 U.S. 234, 236 (1968) (per curiam) ("[0]bjects falling in the plain view of an officer who has a right to be in the position to have that view are subject to seizure and may be introduced in evidence."); Ker v. California, 374 U.S. 23, 42-43 (1963); and even earlier, Marron v. United States, 275 U.S. 192 (1927), and United States v. Lee, 274 U.S. 559 (1927) (finding that no "search" had occurred when coast guard used searchlight to view deck of adjacent boat and saw cases of whiskey).

14403 U.S. 443 (1971). 
seizure and subsequent search of an automobile in plain view in a murder suspect's driveway. ${ }^{15}$ Justice Stewart's plurality opinion ${ }^{16}$ held that where police have some prior justification for being in position to view an object, the viewing of the object is inadvertent, ${ }^{17}$ and the incriminating nature of the object is "immediately apparent," ${ }^{18}$ police may seize evidentiary items in plain view without first obtaining a warrant. Applying this standard, the Court compelled exclusion of the evidence that had supported Coolidge's conviction, concluding that the particular seizure of the automobile was not within the plain view exception because discovery of the car was not inadvertent. ${ }^{19}$

In Texas v. Brown, a different Court plurality expanded upon the holding in Coolidge, stating that "[t]he seizure of property in plain view involves no invasion of privacy and is presumptively reasonable." ${ }^{\text {"20 }}$ Brown's car was stopped by police at a traffic checkpoint where an officer shined a flashlight into the front seat area. The officer observed Brown drop an uninflated and knotted opaque balloon of the sort commonly used to store and to disguise narcotics. He also saw several plastic vials, some loose white power, and an open bag of balloons in the glove compartment. The officer seized the balloon, which was later examined by a police chemist without a warrant; it contained heroin. A plurality of four justices upheld the validity of the seizure and subsequent search on the basis of the plain view exception. Justice Rehnquist's opinion asserted that the "immediately apparent" requirement in Coolidge was "an unhappy choice of words" that simply restated the tradi-

1s The police had obtained a warrant, but it was found to be defective because it was issued by the attorney general involved in the investigation rather than by a "neutral and detached magistrate." Id. at 449.

${ }^{16}$ The abundance of opinions filed in Coolidge has led to considerable debate regarding which sections were supported by which justices. The section on plain view was supported by no more than a plurality of the Court. See, e.g., Charles E. Moylan, Jr., The Plain View Doctrine: Unexpected Child of the Great "Search Incident" Geography Battle, 26 Mercer L. Rev. 1047, 1048-50 (1975) (although it is not clear that Justice Stewart wrote for any more than four justices, courts nevertheless generally regard his opinion as "the law of the land"); Wayne R. LaFave, Warrantless Searches and the Supreme Court: Further Ventures into the "Quagmire," 8 Crim. L. Bull. 9, 10 \& n.3. (1972) (confusion still exists about plain view after Coolidge).

${ }^{17}$ In Note, The Supreme Court, 1970 Term, 85 Harv. L. Rev. 38, 244-45 (1971), the commentators argue that an inadvertence requirement creates an anomalous situation because the police must argue that they did not have probable cause to obtain a warrant, while defendants must argue that police did have probable cause. "Such a scenario," they would conclude, "would hardly encourage police truthfulness." Id. at 245.

18403 U.S. at 466.

18 Id.

${ }^{20} 460$ U.S. 730,741 (1983). 
tional probable cause requirement: once the viewing provides probable cause, no warrant need issue for either a search or a seizure. The plurality also suggested that suspicion amounting to less than probable cause might support a search or seizure in some circumstances. ${ }^{21}$

The expansive tone of the Brown plurality was considerably tempered last term, however, as a six-justice majority of the Court narrowed the plain view exception in Arizona v. Hicks. ${ }^{22}$ In Hicks, police had properly entered an apartment in a warrantless search-justified by exigent circumstances-for weapons and gunmen. While in the "squalid" apartment, the police moved some conspicuously expensive stereo components in order to record serial numbers beneath, and this information later revealed that the components had been stolen. Writing for the majority, Justice Scalia rejected the argument that anything less than probable cause would suffice to support either a search or seizure of an item in plain view, and held that moving the equipment "even a few inches" constituted a search for which probable cause was a prerequisite. Rejecting the dissenters' contention that a "cursory inspection," short of a "full-blown search," should be permitted without probable cause, the Court drew a sharp distinction between mere visual inspection and more intrusive conduct, holding that the distinction between looking at a suspicious item and moving it even a few inches "is much more than trivial for fourth amendment purposes." In sum, Hicks affirms three distinct requirements for invocation of the plain view exception: there must be prior justification to be in the protected area where the viewing is made; there must be probable cause to justify any intrusion beyond visual inspection; and discovery of the suspect item must have been inadvertent. ${ }^{24}$

12 Id. at 742,$741 ; 739,742$ n.7. But as to the last suggestion, see Hicks, 107 S.Ct. at 1153 (requiring probable cause to support a plain view search or seizure).

32107 S.Ct. 1149 (1987).

23 Id. at 1152-54. The Court continued:

As already noted, a truly cursory inspection-one that involves merely looking at what is already exposed to view, without disturbing it-is not a 'search' for Fourth Amendment purposes, and therefore does not even require reasonable suspicion. We are unwilling to send police and judges into a new thicket of Fourth Amendment law, to seek a creature of uncertain description that is neither a plain-view inspection nor yet a 'full-blown search.' Nothing in the prior opinions of this Court supports such a distinction.

Id. at 1154.

24 In Hicks, Justice White wrote separately to stress that the inadvertence requirement

"has never been accepted by a judgment supported by a majority of this Court." Id. at 1155. However, at least five justices appear to support the requirement, as the three dissenting 
B. The Plain Feel Approach

Prior to Hicks, four courts had explicitly recognized a plain feel exception to the warrant requirement, ${ }^{25}$ although one was subsequently overruled with respect to the plain feel issue and the opinion of another has been deleted by order of the state supreme court. ${ }^{26} \mathrm{~A}$ few other courts implicitly have acknowledged a plain feel exception, by asserting that tactile detections could be subsumed within the framework of the plain view exception or by otherwise approving a search or seizure based on tactile information. ${ }^{27}$ Unfortunately, courts that have approved plain feel searches have failed to explain the contours of this new exception to the warrant requirement.

In United States v. Ocampo, ${ }^{28}$ the Second Circuit became the first court to apply a plain feel exception. In Ocampo, police searched two automobiles in the course of arresting the occupants on suspicion of drug and immigration violations. In addition to searching various items, the officers legitimately seized a paper bag that was taped closed and partially covered by clothing. By feeling the outside of the bag the officers determined that it contained currency, and they opened the bag to confirm their suspicions. Applying a " "plain feel' version of the 'plain view' doctrine," the court held that the search of the bag did not violate the fourth amendment. The court reasoned that "[w] here the contents of a container are easily discernible by frisking the exterior of a package, there is little likelihood that the owner could reasonably expect any substantial degree of privacy."29

The Ocampo court's plain feel exception appeared to depend heavily on a distinction between containers. But this distinction is of questionable authority because of the Supreme Court's decision

justices invoked it in Hicks, 107 U.S. at 1155-59, and Justices Brennan and Marshall joined the pertinent sections of Justice Stewart's opinion in Coolidge, 403 U.S. at 445 . Lower courts also consider it the law. See, e.g., United States v. Reed, 726 F.2d 339, 343 (7th Cir. 1984).

${ }^{25}$ See Ortiz, 683 P.2d 822.

${ }^{28}$ See Waterbury, 191 Cal.Rptr. 835. For a decision rejecting the approach of those cases, see Leake v. Com., 220 Va. 937, 265 S.E.2d 701 (1980) (where police stopped defendant for questioning and shook the paper bag he set down, "grasping and shaking . . . the bag held by the defendant . . . constituted a prying into hidden places ... [and] was a search").

${ }^{27}$ E.g. United States v. Portillo, 633 F.2d 1313 (9th Cir. 1980) (invoking several fourth amendment doctrines to uphold a warrantless search prompted by an apparently inadvertent touch or feel).

${ }^{28} 650$ F.2d 421 (2d Cir. 1981).

29 Id. at 429. 
in United States $v$. Ross. ${ }^{30}$ In Ross, a plurality of the Court rejected the distinction between different containers that is inherent in the Ocampo plain feel exception. No distinction may be made between containers whose contents cannot be perceived through a touch, squeeze, or feel and those that are flimsier or softer such that the contents are detectable by touch:

[A] constitutional distinction between "worthy" and "unworthy" containers would be improper. Even though such a distinction perhaps could evolve in a series of cases in which paper bags, locked trunks, lunch buckets, and orange crates were placed on one side of the line or the other, the central purpose of the Fourth Amendment forecloses such a distinction. For just as the most frail cottage in the kingdom is absolutely entitled to the same guarantees of privacy as the most majestic mansion, so also may a traveler who carries a toothbrush and a few articles of clothing in a paper bag or knotted scarf claim an equal right to conceal his possessions from official inspection as the sophisticated executive with the locked attache case. $^{31}$

This suggests that at least in the context of automobile searches, Ocampo's distinction between squeezing a paper bag (permissible without a warrant) and opening a more sturdy container (impermissible) taken from the car is no longer good authority.

In a decision that survives the letter if not the spirit of Ross, the District of Columbia Circuit adopted a plain feel rule in United States $v$. Russell. ${ }^{32}$ The police, with probable cause to believe there were drugs in Russell's car, stopped the car, ordered Russell and his passengers to stand some distance away, and searched the vehicle. A police officer grabbed a paper bag from under the front seat of the car, and he felt what he believed to be a gun. The court found that the officer "unavoidably felt the outline of a gun as he drew the paper bag out from under the seat. Uncovering what his sense of touch revealed did not require a warrant."ss On rehearing, the court explained that plain view encompasses plain touch and plain smell and held that because it was "immedi-

so 456 U.S. 798 (1982).

31 Id. at 822 .

32655 F.2d 1261 (D.C. Cir. 1981), aff'd in part, vacated in part on reh'g, 670 F.2d 323 (D.C. Cir. 1982). Unlike the Second Circuit's decision in Ocampo, the D.C. Circuit's holding in Russell is unaffected by Ross, because the D.C. Circuit on rehearing "rule[d] out creation of an 'unworthy container' exception." 670 F.2d at 325.

ss 655 F.2d at 1264. 
ately apparent" that the bag contained a gun, the officer was justified in searching the bag and seizing the gun. ${ }^{34}$

In State v. Ortiz, ${ }^{35}$ the Hawaii Court of Appeals invoked the plain feel exception in upholding a warrantless search of a knapsack. In Ortiz, a police officer approached the defendant, who was carrying a knapsack, and the defendant fled. When the officer found him he asked about the knapsack, which then lay on the ground; Ortiz reached out for it but was intercepted by the officer. Grabbing the knapsack and feeling what he believed was the butt of a gun, the officer unzipped the knapsack, removed a gun, and arrested Ortiz. The appellate court agreed with the trial court that there was no exigency to excuse the officer from obtaining a search warrant and that the search exceeded the scope of a proper search incident to arrest. However, the court maintained that the officer "knew when he felt the knapsack that a gun was in it," and thus by analogy to plain view, the gun was properly seized. The court concluded that " $[u]$ nder the plain feel rule, where a government agent's feeling of the outside of a container is justified and weapons, contraband, or evidence of a crime are then immediately, coincidentally, and definitely discerned, a government agent may open the container to remove such items."

The appeals court in Ortiz was convinced that the analogy from plain view to plain feel is powerful. It relied in part on the Supreme Court's suggestion in Arkansas $v$. Sanders that where an item is enclosed within a container that is transparent, of distinctive configuration, or otherwise reveals its contents to an observer, the item may be seized under the plain view rule. ${ }^{37}$ However, on appeal, the Hawaii Supreme Court vacated the plain feel portion of Ortiz, upholding the search instead as a valid protective weapons search under Terry $v$. Ohio. ${ }^{38}$

Similarly, without explanation, the California Supreme Court divested a lower court's plain feel opinion of its authority by order-

ss 670 F.2d at 325 .

ss 4 Haw.App. 143, 662 P.2d 517 (1983), vacated on this issue, aff'd on other grounds, 67 Haw. 181, 683 P.2d 822 (1984).

36 662 P.2d at 521, 529 (emphasis added), 531 (emphasis added) (footnote omitted).

s7 442 U.S. 753, 764-65 n.13 (1979). The rationale in Sanders was subsequently overruled implicitly in Ross, 456 U.S. 798, where, as just noted, the Court rejected such a distinction between containers.

${ }^{38} 683$ P.2d at 824 , applying Terry, 392 U.S. 1. As the court found the search valid under Terry, it purported not to reach the issue on which it had granted certiorari-the plain feel exception to the warrant requirement. See id. at 829 (noted by both majority and dissent). 
ing that it not be officially published. In People $v$. Waterbury, ${ }^{39}$ police summoned to investigate "an incident" at the Waterbury home found the defendant crouched on the floor of the front room, wounded. Waterbury told police he and his wife had been attacked by an intruder; the police found his wife in the master bedroom, shot dead. A neighbor had informed the police that there might be a child in the house, prompting them to search throughout the house, including several closets. While brushing back clothing to look inside a closet in the master bedroom, an officer felt "a heavy object" inside the pocket of an insulated vest. Thinking that it might be a gun, the officer opened the pocket, removed the gun ostensibly for the purpose of determining whether it was loaded, and placed it back in the pocket.. ${ }^{40}$ On the basis of that information, police obtained a warrant to search the premises and turned up evidence that later was used to convict Waterbury for murder. ${ }^{41}$

Holding that the search on which the warrant was based was reasonable within the meaning of the fourth amendment, the California appellate court applied an "inadvertent plain feel" rule.42 The court stated that "the knowledge that [the officer] thereby gained was as meaningful and accurate as if the container had been transparent and he had seen the gun within the container." "43 Drawing an analogy to the plain view exception, the court found that the officer was legitimately in a position to detect the gun because of the need to locate and possibly help the child, and it emphasized that the discovery of the gun was inadvertent.

Though the California Supreme Court ordered the Waterbury opinion not to be published, it had already tacitly recognized a plain feel exception in People $v$. Chavers. ${ }^{44}$ There police apprehended Chavers and his companion on the basis of descriptions given by the witnesses to a robbery. Observing several items in the car that gave the police probable cause to believe that a gun involved in the robbery would be found in the car, one officer forced open the glove compartment to find a plastic, zippered shaving kit.

3* 142 Cal.App.3d 1010, 191 Cal.Rptr. 835 (1983).

40 191 Cal. Rptr. at 838.

4 In Waterbury, the gun was ultimately seized pursuant to a warrant that was issued on the basis of information from the plain feel search of the vest pocket. In the absence of a plain feel exception to the warrant requirement, the warrant issued on the basis of information obtained from an illegal search would be invalid.

22 Id. at 841, quoting People v. Chavers, 33 Cal.3d 462, 189 Cal.Rptr. 169, 658 P.2d 96, 106 n.5 (1983) (Bird, C.J., concurring in part and dissenting in part).

43 Id.

43 33 Cal.3d 462, 189 Cal.Rptr. 169, 658 P.2d 96 (1983). 
Feeling the contours of what he believed was a gun, the officer opened the kit and saw the weapon, which he then seized.45

The California Supreme Court affirmed the lower court's denial of Chavers's motion to suppress the evidence, noting that the kit was opened only after an "inadvertent[] discover[y], in the course of an entirely legitimate seizure of the kit, that it in fact contained a handgun." formation came through the sense of touch, the knowledge gained was as "meaningful and accurate as if the container had been transparent." "T The court drew this conclusion from a line of California cases that had sanctioned searching the contents of containers based upon various sensory perceptions. ${ }^{48}$

In a separate opinion in Chavers, Chief Justice Bird argued that the kit was subject to search due to exigent circumstances, ${ }^{49}$ but rejected the assumption that the "plain feel" amounted to a plain view. If one accepts that all contents of squeezable containers are in plain view, she suggested, one can always enter them without a warrant. Bird also argued that tactile perceptions are open to greater interpretation than a true "plain view," because the information obtained through the sense of touch is not as meaningful as that obtained through the sense of sight..

In sum, the Second and D.C. Circuits have explicitly adopted

45 Chavers, 658 P.2d at 102.

48 Id. (emphasis added). Prior to reaching the tactile perception issue, the court concluded that the search of the glove compartment was permissible under Ross, 456 U.S. 798, and that the seizure of the kit was permissible under California cases, see, e.g., Wimberly v. Superior Court, 16 Cal.3d 557, 128 Cal.Rptr. 641, 547 P.2d 417 (1976) (finding probable cause to search passenger compartment, but not glove compartment of car after police saw a smoking pipe and marijuana seeds on the floor). Chavers, 658 P.2d at 101-03.

17658 P.2d at $102-03$.

48 In Guidi v. Superior Court, 10 Cal.3d l, 109 Cal.Rptr. 684, 513 P.2d 908 (1973), the scent of marijuana sufficed to justify a further search. In People v. Lilienthal, 22 Cal.3d 891, 150 Cal.Rptr. 910, 587 P.2d 706 (1978), the court held that the "distinctive outward appearance" of a folded piece of paper "effectively revealed the contents." And in People v. Guy, 107 Cal.App.3d 593, 165 Cal.Rptr. 463, 465 (1980) (emphasis added), a police officer lifted a baggie from the trunk of a car and felt a "pliable powdery substance" and concluded "he was holding either cocaine or heroine." After the contents were seized, an analysis disclosed that the substance was the drug PCP. In the course of its opinion, the court noted that the contents were "virtually in plain sight once the baggie was in hand," and the officer "was able to conclude it contained a controlled substance." Id. at 467.

49 Chavers, 658 P.2d at 105-07 (concurring in part, dissenting in part). The "exigent circumstances" exception excuses the warrant requirement where there is some emergency that makes it highly impractical or dangerous to await a warrant. Cupp v. Murphy, 412 U.S. 291 (1973) (search for evanescent evidence); Warden v. Hayden, 387 U.S. 294 (1967) (hot pursuit of felon); United States v. McKinney, 477 F.2d 1184 (D.C.Cir. 1973) (danger to human life).

so 658 P. 2d at 106-07 \& n.5, 107. 
a plain feel exception to the warrant requirement, fashioned after the plain view exception; appellate courts in California and Hawaii have taken abortive steps toward the same result. Other courts seem to have adopted the reasoning of the plain feel courts by asserting that containers "proclaimed their contents." Y1 Yet, analysis of the plain feel exception has been inadequate because the courts that have made reference to it perceive little distinction between it and plain view.

\section{Plain View to Plain Feel: The Flawed Analogy}

As with other exceptions to the warrant requirement, the plain view exception is premised on a balancing of the intrusiveness of a particular category of search or seizure on an individual's privacy or possessory interests, against the strength of the government interest in effecting that intrusion. In considering the intrusiveness of plain view searches and seizures, the Supreme Court has made two distinct characterizations. First, the Court has held that visual inspection of an item in plain view is not a search at all, at least insofar as the police legitimately have access to a protected area, because the antecedent justification for access eliminates any expectation of privacy. ${ }^{\mathbf{2}}$ Second, the Court has suggested that if the visual inspection provides probable cause to search or to seize, the search or seizure is a minimal additional intrusion. ${ }^{53}$ Because the Court will not countenance an exploratory or rummaging search on this basis, ${ }^{54}$ the minimal nature of the intrusion is assured; and because the Court appears to have foreclosed the validity of pretextual attempts to invade protected areas for the very purpose of gaining access to objects thought to be in plain view, ${ }^{\mathrm{BS}}$ the merely "additional" quality of plain view searches and seizures seems protected as well.

Not only has the Court discounted the intrusiveness of particular plain view searches and seizures, it also has been quite impressed with the substantiality of the government interests as-

s1 See Portillo, 633 F.2d 1313 (ostensibly inadvertent touch, leading to a warrantless search and seizure, upheld on rationales other than plain view).

s2 Hicks, 107 S.Ct. at 1152.

ss The minimal nature of the intrusion is implicit in the Court's insistence that plain view will not support a rummaging search. Id. at 1154, quoting Coolidge, 403 U.S. at 466.

s. Id.

Bs Coolidge, 403 U.S. at 471-72; Hicks, 107 S.Ct. at 1171 (O'Connor, dissenting). But see Justice White's concurrence in Hicks, 107 S.Ct. at 1155, insisting that a majority of the Court has never joined the "inadvertence" requirement announced by the Coolidge plurality. 
serted to lie on the other side of the balance. The Court has relied on four interrelated interests: an interest in ensuring against danger (to police and the public) posed by the continued availability of a criminal instrumentality; an interest in preventing the destruction of evidence; an interest in an administrable rule that meets operational needs of the police; and an interest in not requiring the police to turn their backs on patent unlawfulness. ${ }^{56}$

The assumptions on which both sides of this "balance" depend are open to considerable doubt. The claim that no amount of visual intrusion within a protected area invades privacy interests seems too broad..$^{67}$ Moreover, the limitation of the doctrine to "minimal additional" intrusions depends first on scrutiny of subjective police motives to assure "inadvertency" that may well prove ineffective, and second on a malleable distinction between permitted minimal intrusions and exploratory searches-both of which suggest that interposition of a magistrate's decision may not be so "needless" as Justice Stewart suggested in Coolidge. ${ }^{\mathbf{6 8}}$

Just as the intrusiveness of plain view searches and seizures may be understated, so the government interests supporting plain view arguably have been overstated. The safety of police officers and the preservation of potential evidence should be promoted in most instances by other exceptions to the warrant requirement, most notably that for exigent circumstances. The operational requirements and the problem of blatant criminality also seem to be no greater in plain view contexts than in situations in which an officer has no access to a given protected area but nonetheless views items within that area that present probable cause to search or to seize. ${ }^{50}$

${ }^{86}$ Hicks, 107 S.Ct. at 1153-54. Even where the use of deadly force is appraised, police efficacy has been a dominant concern of the Court's fourth amendment doctrine. See Tennessee v. Garner, 471 U.S. 1, 19 (1985) ("We would hesitate to declare a police practice of long standing 'unreasonable' if doing so would severely hamper effective law enforcement.").

${ }^{57}$ See, e.g., Note, The Post-Katz Problem of When "Looking" Will Constitute Searching Violative of the Fourth Amendment, 38 La. L. Rev. 635, 639-41 (1978) ("looking" may invade legitimate privacy expectations); Edward G. Mascolo, The Role of Functional Observation in the Law of Search and Seizure: A Study in Misconception, 71 Dickinson L. Rev. 379, 415-20 (1967) (nonrandom observations invade privacy).

sB Coolidge, 403 U.S. at 468 (warrant may be a "needless inconvenience"). The need is especially great when balancing tests are used: one commentator insists that such tests may be "too manipulable for fair and predictable enforcement if officers [must] distinguish between different levels of privacy, public need, intrusiveness, and types of justifications." Note, The Civil and Criminal Methodologies of the Fourth Amendment, 93 Yale L. J. 1127 (1984).

BE This is reinforced by a hypothetical that Justice Scalia presented at the close of his opinion in Hicks, in which he noted that a police officer viewing suspect items a few feet 
While such arguments have been unavailing in eliminating the plain view exception generally, Hicks does suggest that the Court will be cautious in authorizing any expansion of the plain view doctrine to contexts where the intrusiveness of the government activity is greater or the strength of the government interest is diminished. Although Hicks merely requires probable cause before any warrantless search or seizure of items in plain view can take place, the Court announced its "unwillingness" to authorize any threshold intrusion other than visual inspection even though many courts and commentators had presumed that the particular conduct at issue in the case would be within the natural purview of the plain view exception. ${ }^{60}$

\section{A. Intrusiveness of Plain Feel Detections}

The fundamental problem with relying on the sense of touch as the basis for a warrantless search is that the initial-even if inadvertent-detection is more intrusive than a visual inspection. ${ }^{61} \mathrm{~A}$ tactile encounter generally will provide less information than a visual encounter, primarily because the sighting will usually be of the incriminating object itself, while the tactile contact will usually be with something that surrounds the object in question. This distinction raises two concerns related to the comparative intrusiveness of a plain feel exception. First, the desire to establish probable cause to justify a further search or seizure may make a police officer's initial tactile contact more intrusive than an initial plain view because of the greater uncertainty of the sense of touch. ${ }^{62}$ Second, as

away from the open window of a home would not be able to enter the protected area on the basis of a warrant exception. 107 S.Ct. at 1155 .

For example, consider a police officer on patrol sighting contraband through a living room window. Here there has been a plain viewing, yet the warrant requirement is generally still in force. The explanation is that plain view by itself is never enough to justify a warrantless intrusion. Coolidge, 403 U.S. at 468 . Therefore, there must be a valid warrant or an independent exception to the warrant requirement-for example, "hot pursuit," search incident to arrest, automobile search, or exigent circumstances-in order for the police to gain entry to the constitutionally protected area. See id. at 467; Hicks, 107 S.Ct. at 1153.

so Hicks, 107 S.Ct. at 1158-59 (O'Connor, dissenting), citing 2 LaFave Treatise at § 6.7(b) (1987 ed.) (cited in note 2).

61 This is at least implicit in Terry, which makes clear that an outer body patdown for weapons is a search even though a visual inspection would not be. 392 U.S. at 16 . While the inadvertence requirement in a plain feel case arguably establishes the constitutional line between unwitting feels and purposeful frisks, the fourth amendment-couched in the objective terms of reasonableness-should properly center on the objective reasonableness of the government's conduct, rather than on the subjective intent of the government actor.

oz See, e.g., State v. Broadnax, 98 Wash.2d 289, 654 P.2d 96, 102 (1982) (en banc) (noting that "tactile sense does not usually result in the immediate knowledge of the nature of the item"). 
Chief Justice Bird pointed out in Chavers, touch is open to a wider range of interpretation than sight, ${ }^{63}$ so a plain feel exception likely will result in more fruitless subsequent intrusions due to sensory misinterpretation.

Plain view operates in part on the premise that there is no cognizable expectation of privacy in objects open to viewing, whether they are lying on a car seat or in open view in one's home. ${ }^{64}$ When the government has some antecedent justification for access to such areas, looking at an item in plain view is assumed to be a de minimis additional intrusion upon one's privacy. In contrast, greater subjective and objective expectations of privacy are manifest when people have taken steps to secrete items out of view. Indeed, in United States $v$. Chadwick, the Supreme Court found a constitutionally protected expectation of privacy inherent in a defendant's decision to place personal effects in a closed container. ${ }^{68}$ Because the plain feel cases invariably involve items that are within some form of container, ${ }^{66}$ courts should take account of defendants' demonstrated intent to secrete objects from plain view when assessing the intrusiveness of a plain feel. Failure to do so would contravene the interests recognized in Chadwick.

\section{B. The Government Interest}

Even the greater intrusiveness of plain feel might satisfy the fourth amendment's requirement of reasonableness if the strength of the government's interest were commensurately greater. But the government's interest in searching or seizing items that can be discerned only by touch is more attenuated than that which it can claim in the plain view context.

The foremost interest assigned to the state in the plain view context has been that of preventing the destruction of evidence or the further and possibly dangerous use of contraband; the interest

os 658 P.2d at 107.

of See generally Hicks, 107 S.Ct. at 1152-54.

os 433 U.S. 1, 11 (1977) ("By placing personal effects inside a double-locked footlocker, respondents manifested an expectation that the contents would remain free from public examination.").

"Container" is used here to encompass boxes, bags, luggage, or other structured storage places, as well as less structured areas such as pockets within articles of clothing, wrapping materials, sheets, or even scattered miscellaneous articles. Analytically, whenever an object is out of view it can be said to be within a container. In New York v. Belton, 453 U.S. $454,460,463$ (1981), for example, the Court treated a zippered jacket pocket as a closed container. 
in protecting police officers from danger is already served by the exceptions for exigent circumstances, searches incident to arrests, and stop and frisk situations. But the Court has recognized that concern over destruction of evidence is a very weak ground on which to base an exception to the warrant requirement. ${ }^{67}$ The loss of some evidence is accepted as the cost of maintaining the sanctity of the fourth amendment. As the Court recognized this term in Hicks, "[T]here is nothing new in the realization that the Constitution sometimes insulates the criminality of a few in order to protect the privacy of us all."

Even if one finds the government interests supporting a plain view exception compelling, it is unclear to what degree similar interests support a plain feel exception. Because of the additional uncertainty associated with the detection in the plain feel context, the government cannot assert that its interest in seizing objects is as strong as in situations where the nature of the detected object is clearer. In the plain view context, the suspect generally knows or believes that incriminating evidence has been seen by police, and thus it is quite likely she will try to have the evidence destroyed or removed if the opportunity arises. By contrast, the plain feel suspect is less likely to know that police have made a tentative detection through the sense of touch and to be aware of the need to further secrete or destroy the evidence. Waterbury itself is evidence that a suspect associated with a plain feel search might not know what has been felt and might not take steps to get rid of evidence. $^{\text {eg }}$

\section{A Practical Critique: Expansionary Effects of Plain Feel}

Not only does the government have a diminished interest in effecting plain feel seizures, there is a countervailing doctrinal interest in preserving the careful interplay of fourth amendment rules that already have been generated by the Court regarding containers and warrantless searches. The adequacy of other fourth amendment rules to vindicate the interests that purport to justify

-7 See Coolidge, 403 U.S. at 468, 472; Vale v. Louisiana, 399 U.S. 30, 34-35 (1970). See also United States v. Davis, 423 F.2d 974, 979 (5th Cir. 1970) ("There is almost always a partisan who might destroy or conceal evidence.").

os 107 S.Ct. at 1155.

6D In Waterbury, the defendant had time to get rid of the evidence that had been detected by plain feel, but he did not do so, perhaps because he did not know that the officer had discovered the evidence. 191 Cal. Rptr. at 838. 
plain feel is borne out by the fact that in the plain feel cases themselves, other exceptions to the warrant requirement were invariably at issue. ${ }^{70}$ Exceptions to the warrant and probable cause requirements tend not to produce discrete groups of cases; rather, exceptions often are laid one upon another, and courts may choose to analyze their facts in the light of one exception or another in spite of the government's characterization of its case. Thus, it would be myopic to consider the effects of plain feel in a vacuum-plain feel could arise in such a way that no other exception is implicated, but it has been more likely to arise in the context of other exceptions to the warrant requirement or exceptions to the probable cause requirement. In such cases it has substantial potential to disrupt the carefully crafted limits the Court has attempted to define for those exceptions. ${ }^{71}$ In fact, a survey of other fourth amendment doctrines shows that a plain feel exception to the warrant requirement would confuse any guidance that the current panoply of rules limiting search and seizure may provide to the police.

\section{A. The Snowballing Stop and Frisk}

The first and perhaps most important area of potential overlap is "stop and frisk." In Terry v. Ohio," the Supreme Court ruled that a law enforcement official may conduct limited seizures

30 In Chavers, for instance, Chief Justice Bird noted that the case came within the exception to the warrant requirement for exigent circumstances. $658 \mathrm{P} .2 \mathrm{~d}$ at 102 (concurring in part and dissenting in part). In Ortiz and Waterbury, rejection of the plain feel opinions of the intermediate courts implied a holding that some other exception to the warrant requirement authorized the government conduct at issue. Waterbury, 191 Cal.Rptr. 835; Ortiz, 662 P.2d 517, aff'd on other grounds, 683 P.2d 822. An illustration of the confusing intersection of warrant exceptions that come into play when an inadvertent feel leads to search and seizure may be found in Portillo, 633 F.2d at 1313, which discusses both exigent circumstances and stop and frisk rationales in upholding such a search. 633 F.2d at 1320 .

71 This is closely related to the concerns pertaining to administrability that members of the Supreme Court has expressed in discussions of "bright line rules." Dunaway v. New York, 442 U.S. 200, 213-14 (1979); Robinson v. United States, 414 U.S. 218 (1973); Belton, 453 U.S. 454. For general reviews of these discussions, see Albert W. Alschuler, Bright Line Fever and the Fourth Amendment, 45 U. Pitt. L. Rev. 227 (1984); Wayne R. LaFave," "Caseby-Case Adjudication" Versus "Standardized Procedures": The Robinson Dilemma, 1974 S.Ct. Rev. 127, 141-42. On the appeal of police governance by rules generally, see Carl McGowan, Rulemaking and the Police, 70 Mich. L. Rev. 659 (1972).

An example of administrability nightmares in this area is United States v. Grubczak, 793 F.2d 458 (2d Cir. 1986), where the court avoided the plain feel issue by finding that plain view was properly applied in light of the police officer's unequivocal testimony that he knew that a case contained burglar tools before he picked it up and made a tactile examination.

${ }^{2} 392$ U.S. 1 (1968). 
and searches (patdowns) of the outer clothing of persons whom the officer stops to question, who are suspicious for reasons the officer can articulate and who the officer reasonably believes may be armed and dangerous. The scope of these patdowns must be very limited, the Court warned, because they are not supported by probable cause (and thus are simultaneously exceptions to both the probable cause and warrant requirements), but are "reasonable" searches for the purpose of protecting police and the public. ${ }^{73}$ Because the purpose of these patdowns is to discover concealed weapons, courts have been quite willing to suppress contraband or other evidence of criminality found on the person frisked, on the ground that the particular frisk exceeded the scope permissible under Terry. ${ }^{74}$ Nevertheless, if a seized item proves not to be a weapon but there was reason to believe it might have been, it will not be suppressed if it is contraband or other evidence. ${ }^{75}$ Furthermore, if in the course of a reasonably limited weapons patdown, police find a suspicious bulge that creates probable cause to search further, a more intrusive search might be permissible. ${ }^{76}$

A plain feel rule could have a profound impact on the scope of permissible searches under the Terry regime. Under Terry, police are justified in making warrantless tactile inspections of suspicious persons on less than probable cause. This would seem to satisfy the first prong of the Coolidge test as adopted by the plain feel courts-prior justification to be in the position to make the detection. Assuming that police were to detect something other than a weapon that they believed had some nexus to criminal conduct, the question would arise whether this was an inadvertent or coincidental discovery. So long as the police could demonstrate that the patdown was not a pretext and that they did not have probable cause to believe they would find these items, inadvertence would seem to follow from detection of other seizable items. ${ }^{77}$ Thus, both

$7 s$ Id. at 27.

74 See State v. Collins, 139 Ariz. 434, 679 P.2d 80, 84 (Ariz. App. 1983) (drugs discovered during weapons frisk suppressed); United States v. Del Toro, 464 F.2d 520, 522-23 (2d Cir. 1972) (same); State v. Hobart, 94 Wash.2d 437, 617 P.2d 429, 434 (1980) (en banc) (same); People v. McCarty, 11 Ill.App.3d 421, 296 N.E.2d 862, 863 (1973) (per curiam) (same). But see Colding v. State, 259 Ark. 634, 536 S.W.2d 106, 109 (1976) (drugs found during patdown admissible).

7s See generally John L. Kuipers, Suspicious Objects, Probable Cause, and the Law of Search and Seizure, 21 Drake L. Rev. 252, 256 (1972).

70 E.g., Terry, 392 U.S. at 28-30 (if protective frisk reveals a weapon, officer may reach into pocket of detained suspect).

${ }^{77}$ Inadvertence is negated only where police have probable cause to believe that evidence will be found. See generally Moylan, 26 Mercer L. Rev. at 1083 (cited in note 16). See 
prior justification and inadvertence, two requirements of the plain view test, would likely be satisfied in the Terry setting.

It is the third prong of the plain view test that has significant potential to expand the range of permissible patdowns. Hicks requires that there be probable cause to believe the item is associated with criminality. ${ }^{78}$ The relevant inquiry again is directed to the degree of reliability associated with information obtained from a casual touch of a concealed object. If one believes that this information is rarely reliable enough to provide probable cause to believe an object is evidence of criminality, one would argue that plain feel would have little impact on the scope of Terry searches, because plain feel rarely would be a successful ground for upholding the seizure of items other than weapons. However, undoubtedly police would occasionally be able to convince a court, after the fact, that their touch provided them with the requisite probable cause-for at that point the seized evidence will be before the judge. In these situations, superimposing a plain feel rule upon a stop and frisk would permit the police to make far more significant intrusions than the brief Terry patdown in cases where the initial suspicion did not rise to the level of probable cause to stop the detainee. Thus, one might expect that evidence seized in the course of a Terry search would be suppressed less frequently.

To understand the synergistic intrusiveness of plain feel, consider its effects on Sibron $v$. New York, ${ }^{79}$ where the Supreme Court held inadmissible narcotics found in glassine envelopes seized from Sibron's pocket. ${ }^{80}$ The Court's decision rested on the conclusion that the officer had exceeded the permissible scope of Terry by thrusting his hand into Sibron's pocket. In the presence of a plain feel rule, however, if glassine envelopes were discovered in the course of a properly limited Terry search, Sibron would have lost his suppression argument. The evidence, wholly unrelated to police safety concerns, would be admissible as long as a court could be persuaded that police can "recognize" a glassine envelope when they feel one and that there is reason to be suspicious if one is detected. ${ }^{81}$ All the searching in such Terry cases would be upheld

also Note, "Plain View"-Anything But Plain: Coolidge Divides the Lower Courts, 7 Loyola L.A. L. Rev. 489, 507-14 (1974).

${ }^{78} 107$ S.Ct. at 1154.

392 U.S. 41 (1968).

so Id. at 64-66.

81 When one considers that the Court upheld probable cause based on the plain view of knotted party balloons and some white powder in Brown, 460 U.S. at 742-44, this plain feel scenario is hardly implausible. 
even though it was initiated on less than probable cause to believe that any criminality is afoot and without the prior approval of a neutral and detached magistrate.

\section{B. Expanding the Scope of Search Incident to Arrest}

A second area in which plain feel would have significant erosive effects on the established balance between individual and government interests is the search incident to arrest exception. In New York v. Belton, ${ }^{82}$ the Supreme Court approved the warrantless search of a container in the passenger compartment of an automobile when the occupants were being subjected to custodial arrest. Recalling the holding in the leading case, Chimel $v$. California, ${ }^{83}$ the Court concluded that the passenger compartment of a car is all part of the "grab area"-within the defendant's immediate reach-and that therefore any containers in the passenger area are subject to search. ${ }^{84}$

Several courts have held that the search-incident exception extends to luggage in the possession of arrestees. ${ }^{85}$ However, other courts have declined to extend the search-incident exception to closed containers in the possession of an arrestee outside of the automobile context. ${ }^{86}$ The courts that construe the exception broadly argue that Chimel permits application of the rule to anything that might be reached by an arrestee at the time of arrest and to a broadly defined area of "control."87 Those that follow a narrower rule often argue that unless the container is "immediately associated" with the person of the arrestee, or if the container is in the exclusive control of police, this exception will not apply. ${ }^{88}$

Assuming the search-incident rule does not always permit the search of closed containers, a plain feel rule could expand the search-incident exception. Often an arrestee is in possession of a bag or briefcase at the time of arrest. The fact that these containers are easily seized and removed from the arrestee's possession

82453 U.S. 454 (1981).

s3 395 U.S. 752, 763 (1969) (police validly may search the area within an arrestee's "immediate control" without a warrant).

s4 Belton, 453 U.S. at 460.

ss See LaFave Treatise $\S 5.5(a)$ at $529 \mathrm{nn} .6-8$ (1987 ed.) (cited in note 2) and cases cited therein.

8s Id. § 5.5(a) at 531-32 and cases cited therein.

${ }^{87}$ See, e.g., Chadwick, 433 U.S. at 15 (search of footlocker not valid when it is not immediately associated with arrestee).

ss Id. 
argues against application of a search-incident rule. Search-incident is justified on the dual rationale of safety and preservation of evidence, yet in the absence of any grounded suspicion that the container is concealing an explosive device, there is no reason that a seized container need be searched prior to a magistrate's approval.

Plain feel, however, would allow expansion of warrantless searches of containers far beyond the limited situations where the search-incident exception is justified. Plain feel suggests that whenever police inadvertently feel something in the container that they have probable cause to believe is the fruit or instrumentality of criminal activity, they may open the container and seize the item. Of course, once police use plain feel to gain access to the container, anything they then see is in plain view and can be seized if associated with criminality. The net effect of plain feel in the search-incident context would be to throw open the search of accompanying containers to highly subjective interpretations, after the fact, of what was felt by the police and what they were entitled to conclude from these perceptions. It would also mean, in opposition to the holding in Ross, that those carrying metal briefcases would be granted a high level of immunity from container searches, while those carrying the same articles in malleable briefcases would receive less protection.

\section{The Tension Between Plain Feel and the Container Decisions}

As was noted previously in the discussion of United States $v$. Ocampo, there is substantial tension between a plain feel exception and Supreme Court container search decisions. First, a plain feel exception applied to containers contravenes the spirit of both Ross, which abolished distinctions based on the nature of the container, ${ }^{89}$ and Chadwick, which acknowledged that a decision to place personal effects in a closed container manifests a heightened expectation of privacy. ${ }^{90}$ Moreover, adoption of a plain feel exception would compound the analytical confusion created by a series of virtually irreconcilable Supreme Court decisions pertaining to container searches.91

89456 U.S. at $821-22$.

${ }^{\circ 0} 433$ U.S. at 13.

21 Compare Chadwick, 433 U.S. at 13 (use of footlocker to store personal effects manifests protected expectations of privacy), with Chambers v. Maroney, 399 U.S. 42, 48, 52 (1970) (warrantless search of auto is valid where search of home or office would not be).

The interplay between the automobile exception and the container decisions is particu- 
Even if one accepts the inconsistencies among the container decisions, a plain feel exception to the warrant requirement remains problematic because its limitations are less enforceable than those of other warrant exceptions. Any circumstance in which police lawfully come into contact with containers including bags, luggage, boxes, and the like would become an opportunity for police to give a little squeeze in an effort to detect the contents of the containers; it may be impossible to ensure that plain feels are inadvertent.

Yet even perfect enforcement of the inadvertence requirement would offer little protection to legitimate expectations of privacy. As long as seizing the container is justified, there is ample room for detection when police take containers into their possession. For example, because it is common procedure for police to take custody of accident victims' possessions, the plain feel doctrine would allow police great latitude in searching through an accident victim's belongings after inadvertently feeling a suspicious object. In sum, a plain feel exception not only conflicts with container decisions, but its limitations seem less enforceable and less protective of privacy expectations than other decisions pertaining to containers.

\section{CoNCLUSION}

Courts that have adopted the plain feel exception to the warrant requirement have given it inadequate treatment. Although courts have suggested a clear analogy can be drawn from plain view to plain feel, the rationales underlying plain view do not equally support a plain feel exception. There are fundamental differences between detections by sight and detections by touch that make plain feel a much weaker candidate for a warrant exception and that suggest that plain feels are themselves highly intrusive activities.

larly perplexing. For example, in Belton, 453 U.S. 454, a search incident to arrest decision, the Court held that even in the absence of probable cause, police may search the entire passenger compartment of the arrestee's car and any closed containers found therein, as long as there is a full custodial arrest. In Ross, 456 U.S. 798, the Court held that where a vehicle is subjected to a valid warrantless search based upon probable cause, any closed containers within any portion of the car may be searched as long as the items that are the basis of the search could be contained therein. An important though uncertain limitation on the automobile exception is that if probable cause focuses only on a particular container that happens to be in an automobile, the exception may not permit the warrantless search of the container. Compare Chadwick, 433 U.S. 1 (footlocker suppressed where officers had no probable cause to search vehicle), with United States v. Johns, 469 U.S. 478 (1985) (warrantless search reasonable because suspicion did not "focus" on containers until after search of vehicles had begun). 
Not only does plain feel fail fourth amendment standards outright, but it threatens to flout the rules that now guide police in discrete contexts such as the treatment of investigative stops, searches incident to arrest, and containers. Warrantless searches and seizures should be impermissible if they are based solely on information obtained through the sense of touch.

David L. Haselkorn 